Corby, Vanessa ORCID:

https://orcid.org/0000-0002-4019-9195 (2017) The Affirmation of Social Class in the Drawings of Sally Taylor. Drawing: Research, Theory, History, Practice, 2 (2). pp. 363-374.

Downloaded from: http://ray.yorksj.ac.uk/id/eprint/2295/

The version presented here may differ from the published version or version of record. If you intend to cite from the work you are advised to consult the publisher's version: https://doi.org/10.1386/drtp.2.2.363_1

Research at York St John (RaY) is an institutional repository. It supports the principles of open access by making the research outputs of the University available in digital form. Copyright of the items stored in RaY reside with the authors and/or other copyright owners. Users may access full text items free of charge, and may download a copy for private study or non-commercial research. For further reuse terms, see licence terms governing individual outputs. Institutional Repository Policy Statement

\title{
RaY
}

Research at the University of York St John

For more information please contact RaY at ray@yorksj.ac.uk 
Title The affirmation of social class in the drawings of Sally Taylor

Author Vanessa Corby

\begin{abstract}
The drawings of British artist Sally Taylor (1977) are composed of heads of various descriptions: blockheads, confused heads, hysterical heads, heads with mouths and heads without, heads full of menace and heads full of glee. The pressure of these recurring motifs, which emerge from as many as two hundred drawings a day, mark out Taylor's practice as an active negotiation of repetition and difference. Norman Bryson famously characterised drawing as an act that resists the finality of the image to instead suspend a moment of 'becoming' (Bryson 2010: 150). The nuanced consistency of Taylor's prolific output exemplifies Bryson's understanding of the medium. What interests me here, however, are the performative aesthetic and material operations that make these drawings call to one another and their audience. The aim of this critical essay is to consider the inextricable relationship between form and content in the works Taylor exhibited in That Head That Head at the Rabley Drawing Centre, Wiltshire (26 September - 29 October 2016). To do so, I argue, is to situate their aesthetic as a negotiation and transformation of the social politics of making art in Great Britain at the beginning of the Twenty-first Century. More particularly, this short essay's reading of her work stands as a provocation to the vilification of the working classes in the run up to and after the EU referendum and, in doing so, testifies to the necessity for Taylor's project.
\end{abstract}

\title{
Keywords
}

drawing, social class, affirmation, Brexit, displacement, academy, material

\section{Author's Biography}

Vanessa Corby trained as a painter in the early 1990s before undertaking a $\mathrm{PhD}$ in feminist theory, history, and criticism of the visual arts at Leeds (2002). Her research mobilises the material operations of art practice to rethink its discourses and histories. She has written extensively on the work of Eva Hesse (Prestel, 2006, I B Tauris, 2010) and has embarked on a new book project entitled Art and the Social Animal: Cooperation, Materials and Making (2019). She is currently Senior Lecturer in Theory, History and Practice of Fine Art at York St John University.

\author{
Dr Vanessa Corby \\ Rm QEM04 \\ School of Art, Design and Computer Studies \\ York St John University \\ Lord Mayor's Walk \\ York \\ YO31 7EX
}

v.corby@yorksj.ac.uk

07788807280 


\section{The affirmation of social class in the drawings of Sally Taylor}

The drawings of British artist Sally Taylor (1977) are composed of heads of various descriptions: blockheads, confused heads, hysterical heads, heads with mouths and heads without, heads full of menace and heads full of glee. The pressure of these recurring motifs, which emerge from as many as two hundred drawings a day, mark out Taylor's practice as an active negotiation of repetition and difference. Norman Bryson famously characterised drawing as an act that resists the finality of the image to instead suspend a moment of 'becoming' (Bryson 2010: 150). The nuanced consistency of Taylor's prolific output exemplifies Bryson's understanding of the medium. What interests me here, however, are the performative aesthetic and material operations that make these drawings call to one another and their audience. The aim of this critical essay is to consider the inextricable relationship between form and content in the works Taylor exhibited in That Head That Head at the Rabley Drawing Centre, Wiltshire (26 September - 29 October 2016). To do so, I argue, is to situate their aesthetic as a negotiation and transformation of the social politics of making art in Great Britain at the beginning of the Twenty-first Century.

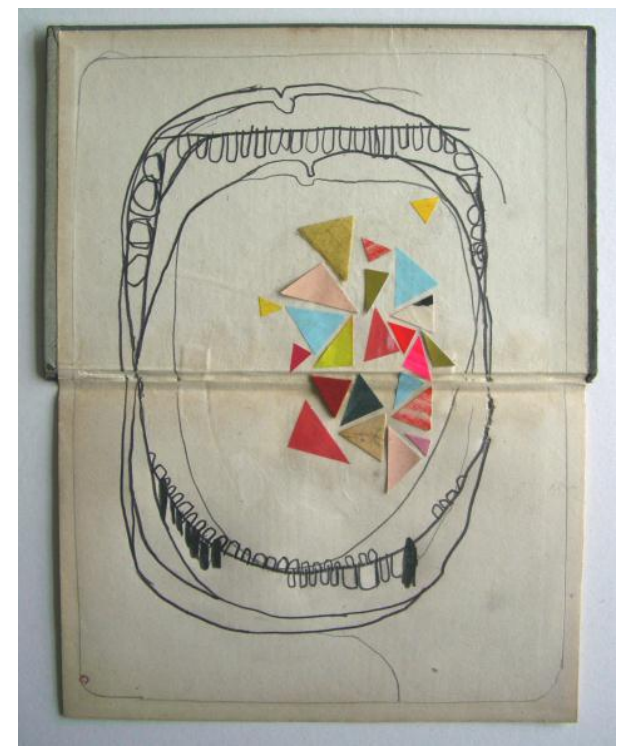

Figure 1: Sally Taylor, Wide Mouth with Triangles, (2011)

This analysis has emerged from the collaboration between myself and the artist, which dates back to the artist's solo exhibition All Say the Same at the Ryedale Folk Museum (2011). Our cooperation has emerged from our shared positions as makers, mothers, thinkers, and educators from working-class backgrounds. To acknowledge this essay's debt to this collaboration is to position its understanding of 'class' in the lineage of E. P. Thompson's classic book The Making of the English Working Class (1963). For Thompson class was not a 'thing': a homogenous group whose specificity could be determined by economic circumstance or defined by a string of working-class credentials. Rather, he argued that it is a 'process' through which 'social relationships' and 'roles' come to be lived as complex, 'historically' indebted 'phenomenon' (Thompson 1982: 8-9). It is through the interaction of differing social groups that a lacking subjectivity is conferred on the working-class; a narrow world view indicative of a lack of understanding, an inadequate vocabulary or the wrong vocabulary, the absence of etiquette and grace. It is in this setting that the objective tone prized by academic writing becomes problematic. Scholarly distance may be able to articulate modes of alterity up to a point, but to admit only one mode speech into the academy is to deny the impact of that difference as a lived experience. The appeal to intellectual rigour 
occludes the potential of writing as a practice with which to contest legitimized and delegitimized means of knowledge production.

The autobiographical voice that marks this essay first of all therefore registers what Nancy Paglia called her 'unresolved stance' between her modes of being in the academy and from the working-class (Paglia1995: 183). To borrow from Shoshana Felman's writing on sexual difference, this essay's tone is indebted to the 'bond of reading' through which the politics of difference are 'engendered' by reading art and theory with our 'own lives' (Felman 1993: 12-13). That bond emerged through the interviews conducted for the Ryedale exhibition catalogue. It argued that the raw materiality of drawings such as Wide Mouth with Triangles (2011, Fig.1) consisted of a 'mute articulacy' whose fragmented uncouth utterances actively worked the legacies of classed experience for the artist and her audience thereby questioning the exclusivity of much conceptually based contemporary art. The years have only affirmed many of the arguments made in the Ryedale essay and in many respects Taylor's work is still 'saying' the same thing. What has changed, however, is the sociopolitical landscape in which her practice can be articulated. This short essay's reading of her work stands, therefore, as a provocation to the vilification of the working classes in the run up to and after the EU referendum and in so doing testifies to the necessity for Taylor's project.

\section{From the ground up}

Confused Head 43 (2016, Fig.2) is a drawing that employs POSCA pen on found paper. Like many works that predate this series the ground is formed from the endpapers of discarded books that the artist has sourced from car boot sales in and around North Yorkshire. These lowly beginnings embed Taylor's drawings within the opening and closure of a now absented text. The book's spine is now a rift, crudely patched with masking tape. The deblures, in this case made from paper, are embossed by the binding and cloth beneath their surface, offering a readymade frame to which Taylor's composition must respond. The paper itself is off-white, worn with use and grease stained: evidence of its age and prior use. The book's content, hitherto protected by this cover, remains unknown to the viewer. Whether fiction or non-fiction the information contained therein is no longer the subject of the book's being. Rather the act of appropriation has emptied out its extant material and assigned to it, like Taylor's Heads, a kind of blankness that speaks volumes.

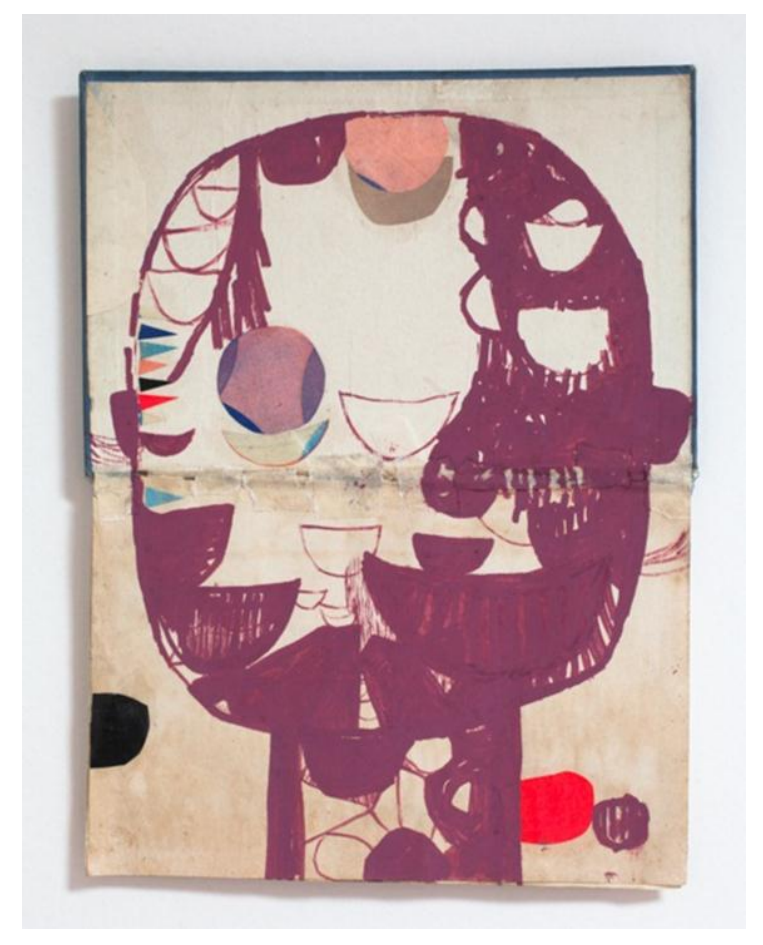

Figure 2, Sally Taylor, Confused Head 43, (2016) 
This ground and its image embody the artist's preoccupation with drawing as a paradoxically immediate yet recalcitrant, non-textual, non-digital mode of communication. From the mid-1960s onwards the Poststructuralists argued that cultural texts possessed a labyrinthine character. Text was not, as had been supposed, merely a transparent vehicle for the ready consumption of 'knowledge'. This offered artists one way to approach the enigmatic communication between artist, artwork, and viewer. Conceptualism revelled in this play of language; a play that was extended to the semiotics of the image. While 'the meaning' of the image may have been unobtainable a multifarious play of meaning has been nonetheless legible. The privilege given to images, representation, and text throughout the era of Critical and Cultural theory sought to redress Modernism's bifurcation of art and life under the stewardship of critic Clement Greenberg (1909-1994); what Pierre Bourdieu censured in Distinction (1979) as the aesthetic of the 'pure gaze' versus the 'barbarous taste' of 'common people' (Bourdieu 2006: 30-32). Greenberg's bifurcation of culture, between kitsch 'fit' for the 'peasants', and 'true art' for the intellectual elite, became a primary target for critical and cultural theorists working through the legacies of the Frankfurt School (Greenberg 1988: 12). Their interrogation of the place and production of art within and for society employed a language and gave birth to a set of practices whose impenetrability largely exceeded the codes of true art that they hoped to destabilise.

As the Warwick Report (2015) made clear, participation in the arts is on the decline. Cultural activities remain the province of middle class aesthetes and intellectuals who already possess the necessary wherewithal to decode their encounters. What this stream of highly technical intellectual consciousness has obscured, as Coole and Frost have recently argued, is attention to questions of materiality (Coole \& Frost 2010: 3). Therefore, the privilege given to intellectual, representational encounters with art has ensured that culture comes from the top down rather than, to borrow from the British art critic, anarchist, and poet Herbert Read (1893-1968) 'from the bottom upwards' (Read 1941: 54)

In his classic essay To Hell with Culture (1941), penned only two years after Greenberg's divisive and much more well-known 'Avant-Garde and Kitsch' (1939), Read argued that there is a 'common assumption' that it is the responsibility of the individual to learn the 'language of that strange country' called art and so 'gradually lift himself on to the cultured level [but] such an assumption is fundamentally wrong, and fundamentally undemocratic' (Read 1941: 44-45). Authorities on art, he continues

Are right to assume that an impenetrable barrier exists between their culture and the worker: they are wrong to imagine that the worker has no cultural sensibility. The worker has as much latent sensibility as any human being, but that sensibility can only be awakened when meaning is restored to his daily work, and he is allowed to create his own culture (Read 1941: 46)

New York's rise to prominence as the centre of the art world and Critical and Cultural Theory's battle with Greenberg set his form of Modernism as the only form. As Michael Paraskos has argued what became marginalised and what Taylor's always immanent, but never realised, communication affirms is Read's more democratic brand of Modernism (Paraskos 2008).

\section{Material sensibility, difference and containment}


Since its earliest beginnings Taylor's practice has rejected the 'clever' conceptualism and push towards representation that sanitised art of its material sensibility. Taylor's unruly practice resonates with what John Sumser identifies as the gap between the 'labor' and 'exchange' theories of work. The working-class, including working-class intellectuals see work 'in terms of 'labor theory': that is the 'energy required to transform raw materials' (Sumser 1995: 299). In the age of ideas heralded by Postmodernism non-working-class people, he argues, see the world in increasingly less 'concrete terms' because often their work often does not entail the transformation of raw materials (Sumser 1995). In this sense it could be said that via a bricolage of discipline specific action, aesthetic decision making, and representation, Taylor's works on paper mouth-off about the privileged status given to 'cognitive' encounters with art. Common to her work and Read's is a fundamental commitment to retain our sensitivity to the physicality of being that characterises our childhood. In To Hell with Culture, Read draws on the writing of John Dewey and Jean Jacques Rousseau to argue that a good education cannot rely on 'book learning' alone but must be grounded in 'sensibility' (Read 1941: pp54-55).

Elementary education should teach children how to use their senses - how to see, to touch, to listen - it is far from easy to learn the full and exact use of these faculties. Then having learned how to use the senses, separately and conjointly, the child should learn how to apply knowledge: how to judge and compare the true reports which are rendered by the senses; how to construct things which give a true sensuous response and, finally, how to construct things which express his growing awareness of the world and its potentialities (Read 1941: pp55-56).

Taylor's working practice aims 'to avoid pre-meditation and ideology that could jeopardise the creative process' and with it the kind of physical sensuous engagement with the world and human experience that Read describes (Taylor 2011: 29). Taylor is thus part of a trend that has been identified in Drawing Now, constituting a shift towards the 'subjective nature of drawing' that possesses a 'characteristic awkwardness and a stubborn resistance to "conventional" subject matter and academic style - a leaning towards a conscious naivety, perhaps, and a denial of the signs of "good drawing" (Tormey \& Selby 2007: ix). Rather her practice enlists what Emma Dexter has named drawing's capacity to act as a space of 'alterity' from which to articulate 'dissent, desire, fear and disorder' (Dexter 2005: 9).

Taylor's wilful embrace of the wrong materials affect a vocabulary of line and surface that resists the autonomy and polish of 'high art' to articulate dimensions of classed and gendered experience. The sensibility that infuses her heads and use of POSCA pens underscore a feminist politics that resolutely refuses to disavow the impact of motherhood on her work. Studio days may be ring-fenced out of necessity, but the day-to-day handling of materials in the company of children cannot help but impact upon an artist's practice. One such impact is Taylor's use of UNI POSCA pens which began when her first child was a toddler. Through the awkward inconsistent flow of the pen the images stutter into existence on the page. 


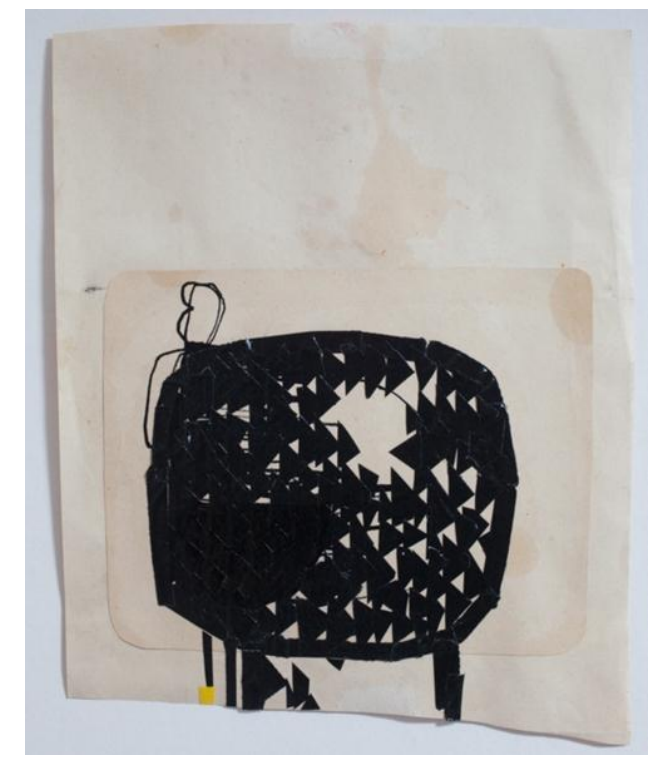

Figure 3: Sally Taylor, Head 10, (2015)

Confused Head 43 has been drawn with a red pigment pen that UNI POSCA named 'Red Wine'. Rather than the deep luscious red of a full glass, it resembles the residue of a glass now empty and is consequently of a flatter mauve hue. What characterises this and many other heads, such as Head 10 (2015, Fig.3), is a fragile yet urgent sense of containment. In Confused Head 43 the crown and left ear formed by the heavy mauve outline are placed adjacent to the impression of the binding. The right ear, however, traverses this impression, stopping short of the blue cloth in which the book is bound. Delineated within its skull are crowds of open, empty mouths: mouths made full by a succession of downward strokes of the pen and four 'troublesome' triangles (Taylor 2011: 9). Each element clamours for the viewer's attention, jostling or talking over its neighbours, straddling the blank chasm of the ground. What this and other drawings reveal is a state of internal variance; a lack of cohesion or connection between these voices that frame an otherwise vacant subject. This cacophonous assemblage of mauve voices appear poised on the point of speeches that are never delivered; an effect which is amplified ten-fold when the drawings are viewed as they were produced, together in Taylor's studio (Fig.4). Nevertheless this tumult is resolutely confined by the lines from which the heads are formed.

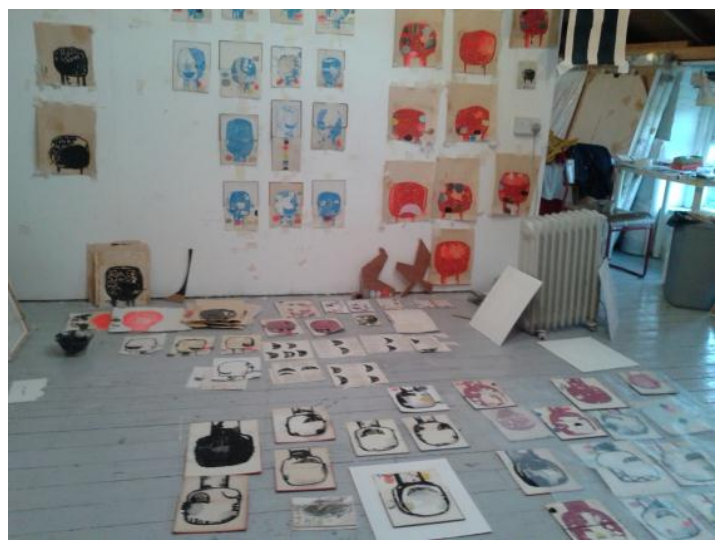


I like to think that Confused Head 43 is mulling over nothing other than the pronunciation of the word 'mauve'. In the United Kingdom one of the most readily identifiable markers of class is speech: Received Pronunciation, characterised by round vowel sounds is synonymous with the educated, formal speech of the middle classes while regional accents earmarked by flat vowels and dropped 'Hs' are indicative of the working-class and often the economic divide between the poorer North and more prosperous South of England. As Simon Garfield notes in the South of England it is 'moave' but in the North it is commonly 'morv' (Garfield, London, 2001) or 'moarve'; is one way right and the other wrong? Taylor, she tells me, would say 'morv.' I on the other hand, hear 'moave' every time I re-read this text, having watched Withnail and I (1985) too many times in my youth. Try as I might, I cannot expunge the image of a menacing Richard Griffiths' whispering to Richard E. Grant in hushed tones 'he's so mauve we don't know what he's planning'. This cultural reference has been in and out of this essay like a yoyo. Its playfulness feels inappropriate. It does not accord with the kind seriousness demanded by exhibition text whose job it is to advocate an artist's practice and assure the reader that the author knows what she is talking about. If this essay is to hold good to its purpose and the rationale of Taylor's practice, however, such acts of self-censorship should be revealed. For they act as a performative index of the class-born fear of saying, as Taylor puts it, the 'wrong thing'.

It hardly seems credible that an analysis of art practice in 2016 remains indebted to arguments made twenty years ago, which sought to reveal the hitherto marginalised experience of working class subjects in the academy. That is exactly the case, however. In 1996 the journal Feminism and Psychoanalysis featured a special issue about social class edited by Valerie Walkerdine. In the article 'Masks of Middle-Class Belonging: Speaking of the Silent, Working-Class Past', American scholar Jane M. Ussher tells the reader that most working-class intellectuals 'feel silenced' by the sense of displacement that casts them as 'outsiders' in the academy where 'middle class values, status and privilege are taken for granted norms' (Ussher 1996: 463). Ussher argues that those scholars who have always known such 'privilege', whose belonging in the academic environment is signified by their speech, modes of address, 'dress and codes of conduct' do not need to acknowledge it (Ussher 1996: 463). Instead their experience has become a universally accepted, although unacknowledged, norm to which others must conform. As Ussher states

Those in transit, who have left working class roots and destinies behind, yet who can never feel completely at home in the comfortable middle class world they have been educated into, wear a mask. To speak of what is behind the mask - the shame, guilt, anger, anxiety; the agony of being frozen in a never-ending limbo between one class and another; the knowledge of never belonging of always being an impostor - would be to risk all. (Ussher 1996: 463)

I think that 'risking all' is precisely what Taylor's practice does. It repeatedly affirms the difference of social class by unveiling the daily containment of an anxiety of ignorance. It is here that the work is at once mute and articulate, proffering a kind of simultaneously raucous yet silent babble that refuses assimilation and bespeaks something of the uncertainty of belonging, (not) knowing, (un)thinking and saying that, to both of us, is an inexorable part of being working-class in cultural environments.

\section{'Blockheadism' and 'balderdash'}


Over the past five years Taylor and I have often and bemoaned the way that social class seemed to have slipped off the radar of the artistic and museal contexts in which we worked. That was until the spring of 2016 when the question of class, or more particularly workingclass culture, re-entered public discourse in a way I have not seen since the Miner's Strike of 1984-85. The catalyst for this debate had been the EU referendum. The working-class were once again grouped into the contemptible 'masses' characterised throughout 'English thought', as Raymond Williams observed, by '"blockheadism, gullibility, bribeability, amenability to beer and balderdash"' (Williams 1985: 95). The reason for this recent wave of criticism had been their support for the 'Vote Leave' campaign. As Lisa Mckenzie, Research Fellow at the London School of Economics, argued in The Guardian on $15^{\text {th }}$ June 'in the last few weeks of the campaign the rhetoric has ramped up and the blame game started' (McKenzie 2016). She continued,

If we leave the EU it will be the fault of the "stupid", "ignorant", and "racist" working class. Whenever working-class people have tried to talk about the effects of immigration on their lives, shouting "backward" and "racist" has become a middle-class pastime (McKenzie 2016).

It now feels, therefore, that to acknowledge working-class beginnings (in my case in Barnsley, South Yorkshire where 83,958 ballots cast out of 122,909 voted 'Leave') is to take a greater risk (Electoral Commission 2016). Taken in this light, the sense of containment exhibited by Taylor's work may well function not as a preservation of the subject against the judgements of the merciless world but the other way around. In some minds, but hopefully not all, it raises the possibility that the absence of a sense of belonging is indicative of working class isolationism and that saying the wrong thing, or nothing at all, truly is a symptom of ignorance. Taylor's practice and this text think differently, however. For in continuing to articulate our practices as makers, thinkers, and crucially educators as an ongoing negotiation of working-class subjectivity we direct our energy to the 'chasm of inequality in the UK and the monsters of a deeply divided and unfair society' that the referendum result revealed (McKenzie 2016).

\section{Responsibility: drawing the human and social class together}

In 1998 sociologist Zygmunt Bauman observed that the proliferation of the term 'underclass', which cast the non-working poor of post-industrialism as layabouts sponging off the Welfare State, had linked 'poverty with criminality'. This strategy, he argued, 'banished the poor from the universe of moral obligations'. He goes on to say:

The substance of morality is the impulse of responsibility for the integrity and well-being of other people who are weak, unfortunate and suffering; criminalization of poverty tends to extinguish and argue away that impulse (Bauman 1998: 77).

As Bauman argues public policy has been more engaged in 'defending the right and proper lives of decent people' from the 'assaults plotted in the mean streets, ghettos and nogo areas' rather than 'defending the poor against the cruelty of their fate' (Bauman 1998:78). In 2016 it has been the issues surrounding immigration that compounded the lack of empathy and moral responsibility felt towards the working-classes; adding racism to the charges of criminality and general dunderheadness. That racism exists is not in question. What should be in question are the means by which the fears and privations of some of society's most vulnerable people are ideologically instrumentalised to achieve economic and political ends. 
Since its resurgence in the early 1990s drawing has come to inhabit a central rather than a peripheral role within contemporary art. In many respects the strength of that position is an affirmation of what Christian Rattemeyer described in 2013 as the 'ubiquity' of the medium (Rattemeyer 2016: 10) or, as Emma Dexter put it in 2005, that 'to draw is to be human' (Dexter 2005: 8). Drawing has been credited with a sensuous materiality that has the capacity to tap and articulate the shared nature of human experience, rendering it a powerful tool for social engagement in the arts. Taylor's repeated affirmation of this potentiality, its 'life force', through her choice of subject matter is a call to responsibility. Her heads ask the viewer to think both in and beyond the gallery about how drawing might intervene in the dehumanisation of this particular cultural other. Taylor's heads are speaking, are you listening?

\section{Word Count 3532}

\section{References}

Bauman, Z. (1998), Work, Consumerism and the New Poor, Open University Press, London.

Bourdieu, P. (2006 [1979]), Distinction: A Social Critique of the Judgement of Taste, Routledge, London.

Bryson, N. (2010), “A Walk for a Walk”s Sake' in Butler, C. H., and Zegher, C. de, eds., On Line: Drawing through the twentieth century, MoMA, New York.

Coole, D. and Frost, S. (2010), New Materialism: Ontology, Agency and Politics, Duke University Press, Durham and London.

Dexter, E. (2005), Vitamin D: New Perspectives in Drawing, Phaidon, London.

Electoral Commission, (2016), EU Referendum Results

http://www.electoralcommission.org.uk/find-information-by-subject/elections-and-

referendums/past-elections-and-referendums/eu-referendum/electorate-and-count-information Accessed Sunday 27 November 2016.

Felman, S. (1993) What Does A Woman Want? Reading and Sexual Difference, John Hopkins, Baltimore.

Garfield, S. (2001), Mauve: How one man invented a colour that changed the world, Faber and Faber, London.

Greenberg, C. (1988), The Collected Essays and Criticism, Volume 1: perceptions and Judgments, 1939-1944, University of Chicago.

McKenzie, L. (2016) 'Brexit is the only way the working class can change anything' https://www.theguardian.com/commentisfree/2016/jun/15/brexit-working-class-sick-racisteu-referendum Accessed Sunday 27 November 2016.

Lapaglia, N. (1995) 'Working-Class Women as Academics: Seeing in Two Directions, Awkwardly,' in C. L. Barney Dews and Caroly Leste Law eds., This Fine Place So Far From Home: Voices of Academics from the Working Class, Temple University Press, Philadelphia. 
Paraskos, M. (2008), Rereading Read: New Views on Herbert Read, Freedom Press, London.

Rattemeyer, C. (2013), 'Introduction' in Perry C, Cashdan M, and Kraus C eds., Vitamin D2: New Perspectives in Drawing, Phaidon, London.

Read, H. (1941), To Hell with Culture, Kegan Paul, London.

Sumser, J (1995) Working it Out: Values, Perspectives and Autobiography, in C. L. Barney Dews and Caroly Leste Law eds., This Fine Place So Far From Home: Voices of Academics from the Working Class, Temple University Press, Philadelphia.

Taylor, S. (2011), Sally Taylor Drawings, Ryedale Folk Museum.

Thompson, E. P. (1963, 1982) The Making of the English Working Class, Penguin, London.

Tormey, J. \& Selby, A. (2007), Drawing Now: Between the Lines of Contemporary Art, (I B Tauris, London.

Ussher, J. M. (1996), 'Masks of Middle-Class Belonging: Speaking of the Silent, WorkingClass Past,' in Valerie Walkerdine ed., Feminism and Psychology: Special Issue on Social Class, Volume 6: 3.

Warwick Commission, (2015) Enriching Britain: Culture, Creativity and Growth http://www2.warwick.ac.uk/research/warwickcommission/futureculture/finalreport/warwick commission_final_report.pdf Accessed Sunday 27 November 2016.

Williams, R. (1985 [1958]), Culture and Society 1780-1950, Penguin, London.

\section{List of Illustrations}

Figure 1 Sally Taylor, Wide Mouth with Triangles, 2011 (Graphite, collage on book cover, $25 \mathrm{x} 20 \mathrm{~cm}$ ) Private Collection. Photo courtesy of the artist

Figure 2 Sally Taylor, Confused Head 43, 2016 (POSCA Pen, collage on book cover, 25x $19 \mathrm{~cm})$, Private Collection, Photographer Victoria Harley

Figure 3 Sally Taylor, Head 10, 2015 (Ink, gaffer tape on found paper, paper, 36x32cm) Private Collection, Photographer Victoria Harley

Figure 4 Taylor's Studio, Stonegrave, North Yorkshire, July 2016. Courtesy of the artist. 
